\title{
Stein i Stuttgart ${ }^{1}$
}

\section{Ragnild Lome}

Gertrude Stein ble introdusert i det tyskspråklige litterære miljøet på 1950-tallet gjennom Stuttgart-skolen, i kretsen rundt Max Bense. Resepsjonen hadde inntil da vært sporadisk, kun Steins The Autobiography of Alice B. Toklas var tilgjengelig i tysk språkdrakt (utgitt på Zürcher Arche-Verlag i 1955). Johanna Schwanauers oversettelse av Steins tale «What Are Master-pieces and Why Are There So Few of Them» (1935), trykt i Benses tidsskrift augenblick i mai 1958, kan ses som startskuddet på et intenst kjærlighetsforhold til Stein; Stein ble en inspirasjonskilde, en slags algoritme som genererte ideer og tekster hos forfattere, programmerere og akademikere. Poeten, kritikeren og forfatteren Helmut Heißenbüttel hyllet den amerikanske forfatteren for å gjøre skillet mellom form og innhold irrelevant og dermed skape muligheter for at et annet type språk kunne

1 Kilde: Reinhard Döhl: «Gertrude Stein und Stuttgart - eine Spurensuche». Tale på Wilhelma-teateret i Stuttgart, 2. oktober, 1993. URL: http://www.stuttgarterschule.de/steinstu.htm 
oppstå. Max Bense trakk linjer mellom refleksjonene til Alfred North Whitehead og Gertrude Stein, og Elisabeth Walther la vekt på hvordan gjentakelsene hos Stein ikke bare var formalistiske, språklige virkemidler, men gjentakelser med eksistensielle ringvirkninger.

Særlig viktig for Stuttgart-miljøet ble portrettene til Stein. Portrettet «If I Told Him. A Completed Portrait of Picasso» ble så populært at flere i Stuttgart-miljøet lærte det utenat og lagde nye versjoner av det.

På tysk har Steins original fått navnet «Wenn ich es ihm sagte»:

Wenn ich es ihm sagte, hätte er es gern. Hätte er es gern, wenn ich es ihm sagte. Hätte er es gern, hätte Napoleon, hätte Napoleon, hätte, hätte er es gern. Wenn Napoleon, wenn ich es ihm sagte, wenn ich es ihm sagte, wenn Napoleon. Hätte er es gern, wenn ich es ihm sagte, wenn ich es ihm sagte, wenn Napoleon. Hätte er es gern, wenn Napoleon, wenn Napoleon, wenn ich es ihm sagte. Wenn ich es ihm sagte, wenn Napoleon, wenn Napoleon, wenn ich es ihm sagte. Wenn ich es ihm sagte, hätte er es gern, hätte er es gern, wenn ich es ihm sagte. Schlösser schliessen und öffnen sich wie Königinnen es tun. Schlösser schliessen und Schlösser und so schliessen Schlösser und so und so Schlösser, und so schliessen Schlösser und so schliessen Schlösser und Schlösser und so. Und so schliessen Schlösser und so und also. Und also und so und so und also. Lassen Sie mich erzählen, was Geschichte lehrt, Geschichte lehrt.

\section{En variant fra Stuttgart:}

Wenn aber der Dienstweg eingehalten wird wenn Fragen. Wenn aber der Dienstweg eingehalten wird wenn Fragen Fragebogen. Wenn aber der Dienstweg eingehalten wird wenn Fragen Fragebogen und Antworten. Wenn aber der Dienstweg eingehalten wird wenn Fragen Fragebogen und Antworten in doppelter Ausfertigung. Wenn aber der Dienstweg eingehalten wird wenn Fragen Fragebogen und Antworten in doppelter Ausfertigung wenn Fragen. Wenn aber der Dienstweg eingehalten wird wenn Fragen 
Fragebogen und Antworten in doppelter Ausfertigung wenn Fragen Fragebogen. Wenn aber der Dienstweg eingehalten wird wenn Fragen Fragebogen und Antworten in doppelter Ausfertigung wenn Fragen Fragebogen und Antworten. Wenn aber der Dienstweg eingehalten wird wenn Fragen Fragebogen und Antworten in doppelter Ausfertigung wenn Fragen Fragebogen und Antworten wenn Fragen. Wenn aber der Dienstweg in doppelter Ausfertigung eingehalten wird hochachtungsvoll!

«If I Told Him. A Completed Portrait of Picasso» er oversatt til dansk som «Hvis jeg sagde det», og siden en av våre redaktører, Solveig Daugaard, har været med-oversetter, har vi trykket dette Stein-portretter i den første utgaven av Sensorium Journal, både på dansk og engelsk. 